\title{
Telemedicine: A systematic review of economic evaluations
}

\author{
Bahram Delgoshaei ${ }^{1}$, Mohammadreza Mobinizadeh$^{2}$, Reyhaneh Mojdekar ${ }^{3 *}$, Elham Afzal ${ }^{4 *}$, \\ Jalal Arabloo ${ }^{5}$, Efat Mohamadi ${ }^{6}$
}

Received: 23 Feb 2016 Published: 20 Dec 2017

\begin{abstract}
Background: Telemedicine is an expanded term in health information technology that comprises procedures for transmitting medical information electronically to improve patients' health status. The objective of this research is to evaluate the cost-effectiveness of telemedicine interventions in various specialty areas.

Methods: The Cochrane Library and Centre for Review and Dissemination were searched up to February 2013 using Mesh. Studies that compared any kind of telemedicine with any other routine care technique and used cost per health utility unit's outcomes were included.

Results: Twenty-one articles were included. According to the included studies, it seems that using telemedicine in cardiology can be effective and cost-effective enough but pre-hospital telemedicine diagnostics program are likely to have little impact on acute myocardial infarction fatality. In pulmonary, telemedicine can be a cost-effective strategy for delivering outpatient pulmonary care to rural populations which have limited access to specialized services, but telemedicine is not cost- effective in asthma and airways cancer. In ophthalmology, especially in the diagnosis of diabetic retinopathy, the use of telemedicine is a cost-effective tool. In dermatology, telemedicine is not cost-effective enough in comparison of conventional cares. In other fields such as physical activity and diet, eating disorder, tele-ICU, psychotherapy for depression and telemedicine on ships, telemedicine can be used as a cost-effective tool for treatments or cares.
\end{abstract}

Conclusion: Most of the included studies confirmed that telemedicine is cost-effective for applying in major medical fields such as cardiology; but in dermatology, papers could not confirm the positive capability of telemedicine.

Keywords: Telemedicine, Economics, Review

Copyright@ Iran University of Medical Sciences

Cite this article as: Delgoshaei B, Mobinizadeh M, Mojdekar R, Afzal E, Arabloo J, Mohamadi E. Telemedicine: A systematic review of economic evaluations Med J Islam Repub Iran. 2017 (20 Dec);31:113. https://doi.org/10.14196/mjiri.31.113

\section{Introduction}

Telemedicine is an extended term in health information technology that comprises procedures for transmitting medical information electronically to improve patients' health status (1). Telemedicine procedures provide same or better clinical outcomes compared to traditional care (2). "Telemedicine can be beneficial to patients living in isolated communities and remote regions, who can receive care from doctors or specialists far away without the patient having to travel to visit them" (3). "There is increas-

Corresponding author: Dr Reyhaneh Mojdekar, r_mojdehkar1@yahoo.com DrElham Afzal, Ihmafzal68@yahoo.com

1. Department of Health Services Administration, Iran University of Medical Sciences, Tehran, Iran.

2. National Institute for Health Research, Tehran University of Medical Sciences, Tehran, Iran.

3. Social Security Organization, Tehran, Iran.

4. Hospital Management Research Centre, Iran University of Medical Sciences, Tehran, Iran.

5. Department of Health Management and Economics, School of Public Health, Tehran University of Medical Sciences, Tehran, Iran.

6. Health Equity Research Center (HERC), Tehran University of Medical Sciences, Tehran, Iran. ing interest in the use of telemedicine as a means of healthcare delivery. This is partly because technological advances have made the equipment less expensive and simpler to use and partly because increasing healthcare costs and patient expectations have increased the need to find alternative modes of healthcare delivery" (4). Although telemedicine interventions were begun some years ago and had good growth so far, the meticulous economic evaluation of these kind programs remains insufficient (5).

$\uparrow$ What is "already known” in this topic:

Telemedicine is an expanded term in health information technology that comprises procedures for transmitting medical information electronically to improve patients' health status.

\section{$\rightarrow$ What this article adds:}

The present study is one of the few studies that systematically review the economic evaluation studies in the field of telemedicine. The results showed that telemedicine is cost-effective for applying in major medical fields such as cardiology; but in dermatology, included papers couldn't confirm the positive capability of telemedicine 


\author{
The results of internet \\ search \\ $(\mathrm{n}=185)$
}

Exclusion articles that were
repeated more than once

130 papers were excluded.

Exclusion articles on the
basis of inclusion-exclusion
\[ (\mathrm{n}=50) \]

20 papers were excluded.

Exclusion articles on the basis of CASP checklist $(n=30)$

9 papers were excluded.

21 papers were included in final phase.

\section{Fig. 1. Flow of papers through the study}

However, economic benefits in the form of similar or better clinical results, or good cost-effectiveness ratios when better clinical status is shown despite higher total costs, may be good reasons to consider the setup of telemedicine (6).

Previous studies concluded that telemedicine is effective and has positive effects. These include therapeutic effects, improved efficiencies in the health services, and practical usability. Other benefits identified were: increased access to health services, cost-effectiveness, improved educational opportunities, heightened health outcomes, improved quality of care, enhanced quality of life and higher social support (7). Also, previous studies showed that there is a lack of knowledge and understanding about the costs and cost-effectiveness of telemedicine (8).

With consideration of these problems, the aim of this research is to evaluate the cost-effectiveness of telemedicine interventions in various specialty fields.

\section{Methods}

\section{Literature Search}

The Cochrane Library and Centre for Review and Dissemination were searched up to February 2013, with no language restriction. MESH database was used in the search strategy (Tables 1 and 2). In the first phase, duplicate papers were removed. In the second phase, the titles and abstracts of the remaining papers were checked for excluding non-relevant studies. In the third phase, the fulltexts of the remaining articles were retrieved and checked against the inclusion/exclusion criteria (Tables 3 and 4).

\section{Inclusion and Exclusion Criteria}

Intervention: All telemedicine interventions.

Population: Patients undewent any kind of telemedicine

Comparators: Standard or another type of care or different telemedicine interventions

Outcomes: Health-related outcomes and costs

\section{Quality Appraisal Method}

The quality of included papers was examined via CASP checklist for Economic Evaluations; this process was performed by one reviewer and was checked by a second one (Fig. 1).

For collecting data from the included studies, a structured form was designed.

\section{Synthesizing Method}

Qualitative analysis was applied for synthesizing of data.

\section{Results}

In this review, twenty-one articles were included, twenty papers were excluded based on the inclusion and exclusion criteria; and nine ones excluded because of poor methodology quality (Fig. 1, Tables 3 and 4); all of the included studies were economic evaluation studies (9-29). One paper was published in 2012 (14), three papers in $2011(11,15,16)$, three in $2010(9,17,27)$, four in 2009 $(12,13,29)$, one in $2008(28)$, one in 2005 (19), three in $2004(20,25,26)$ one in $2002(10)$, one in $2001(21)$, one in 2000 (22), one in 1998 (24) and one in 1995 (23). The retrieved data were synthesized through telemedicine indication of use which was identified by authors in included studies: cardiology, pulmonary, ophthalmology, dermatology and other indications.

\section{A) Cardiology}

Datta et al. in their study which was on the economic evaluation of a nurse-administered behavioral intervention via telephone for control of hypertension among veterans,

\begin{tabular}{lrc} 
Table 1. Search strategy for Cochrane library \\
\hline No. & Search strategy & Number of papers \\
\hline$\# 1$ & Telemedicine & 1073 \\
$\# 2$ & MESH descriptor Telemedicine explode all trees & 20 \\
$\# 3$ & $(\# 1$ OR \#2) & 1073 \\
$\# 4$ & (\#3 In Economic Evaluations) & 83 \\
\hline \multicolumn{4}{r}{} \\
Table & 2. Search strategy for Centre for Review and Dissemination \\
\hline No. & Search strategy & Number of papers \\
\hline$\# 1$ & (Telemedicine) IN NHSEED & 90 \\
$\# 2$ & MESH descriptor Telemedicine explode all trees IN & 84 \\
$\# 3$ & NHSEED & 102 \\
\hline
\end{tabular}

2 http://mjiri.iums.ac.ir

Med J Islam Repub Iran. 2017 (20 Dec); 31:113. 
B. Delgoshaei, et al.

Table 3. The characteristics of included papers

\begin{tabular}{|c|c|c|c|c|c|c|}
\hline $\begin{array}{l}\text { Author } \\
\text { (Reference) }\end{array}$ & Year & Country & Population & $\begin{array}{c}\text { Intervention } \\
\text { (type of telemedicine) }\end{array}$ & Comparison & Outcome indicators \\
\hline $\begin{array}{l}\text { Datta et al. } \\
(9)\end{array}$ & 2010 & USA & Hypertensive veterans & $\begin{array}{c}\text { A nurse-administered, } \\
\text { tailored information } \\
\text { bimonthly for } 2 \text { years via } \\
\text { telephone }\end{array}$ & Nonintervention & $\begin{array}{l}\text { Cost per life-year } \\
\text { saved }\end{array}$ \\
\hline $\begin{array}{l}\text { Agha et al. } \\
(10)\end{array}$ & 2002 & USA & Rural population & $\begin{array}{c}\text { Outpatient pulmonary } \\
\text { subspecialty consultations } \\
\text { via telemedicine (tele- } \\
\text { pulmonary) }\end{array}$ & $\begin{array}{l}\text { 1- Routine care } \\
\text { (patients travel from a } \\
\text { remote site to the hub } \\
\text { site to receive care) } \\
\text { 2- On-site care } \\
\text { (patients receive care } \\
\text { at the remote site) }\end{array}$ & Cost per patient/year \\
\hline $\begin{array}{l}\text { Nelson et al. } \\
\text { (11) }\end{array}$ & 2011 & USA & Stroke patients & $\begin{array}{l}\text { Telestroke a 2-way, } \\
\text { audiovisual technology } \\
\text { that links stroke specialists } \\
\text { to remote emergency } \\
\text { department physicians and } \\
\text { their stroke patients }\end{array}$ & Usual care & $\begin{array}{c}\text { Costs, quality- } \\
\text { adjusted life years } \\
\text { (QALYs) incremental } \\
\text { cost-effectiveness } \\
\text { ratios }\end{array}$ \\
\hline $\begin{array}{l}\text { Graves et al. } \\
\text { (12) }\end{array}$ & 2009 & Australia & $\begin{array}{l}\text { Adults with established } \\
\text { chronic diseases }\end{array}$ & $\begin{array}{c}\text { Telephone counseling } \\
\text { intervention for physical } \\
\text { activity and diet }\end{array}$ & Usual Care & $\begin{array}{l}\text { Cost per quality } \\
\text { adjusted life year } \\
\text { gained }\end{array}$ \\
\hline $\begin{array}{l}\text { Crow et al. } \\
\text { (13) }\end{array}$ & 2009 & USA & $\begin{array}{l}\text { Women with DSM-IV } \\
\text { bulimia nervosa or eat- } \\
\text { ing disorder }\end{array}$ & $\begin{array}{c}\text { Telemedicine cognitive } \\
\text { behavioral therapy }\end{array}$ & $\begin{array}{l}\text { Face-to-face cognitive } \\
\text { behavioral therapy }\end{array}$ & $\begin{array}{l}\text { Cost per recovered } \\
\text { (abstinent) subject }\end{array}$ \\
\hline $\begin{array}{l}\text { Ryan et al. } \\
\text { (14) }\end{array}$ & 2012 & UK & $\begin{array}{l}288 \text { adolescents and } \\
\text { adults with poorly con- } \\
\text { trolled asthma }\end{array}$ & $\begin{array}{l}\text { Mobile phone supported } \\
\text { self-monitoring of asthma }\end{array}$ & $\begin{array}{l}\text { Standard paper based } \\
\text { monitoring strategies }\end{array}$ & $\begin{array}{c}\text { Changes in scores on } \\
\text { asthma control ques- } \\
\text { tionnaire and self } \\
\text { efficacy }\end{array}$ \\
\hline $\begin{array}{l}\text { Rein et al. } \\
(15)\end{array}$ & 2011 & USA & $\begin{array}{l}\text { People with diabetes } \\
\text { with no or early diabetic } \\
\text { retinopathy }\end{array}$ & Telemedicine screening & $\begin{array}{c}\text { Self-referral, biennial } \\
\text { evaluation, and annual } \\
\text { evaluation }\end{array}$ & $\begin{array}{l}\text { Cost per quality } \\
\text { adjusted life year } \\
\text { gained }\end{array}$ \\
\hline $\begin{array}{l}\text { Franzini et al. } \\
\text { (16) }\end{array}$ & 2011 & USA & ICU patients & Tele-ICU program & Nonintervention & $\begin{array}{l}\text { Average daily costs, } \\
\text { costs per case, and } \\
\text { costs per patient }\end{array}$ \\
\hline $\begin{array}{l}\text { Eminović et al. } \\
\text { (17) }\end{array}$ & 2010 & Netherlands & $\begin{array}{c}\text { Patients were referred to } \\
\text { one of the recruited } \\
\text { dermatologists }\end{array}$ & Teledermatology & Conventional process & $\begin{array}{l}\text { Costs per dermatolo- } \\
\text { gy patient care epi- } \\
\text { sode }\end{array}$ \\
\hline $\begin{array}{l}\text { Dowie et al. } \\
\text { (18) }\end{array}$ & 2009 & UK & Babies and children & $\begin{array}{l}\text { A telecardiology service } \\
\text { introduced alongside } \\
\text { outreach clinics }\end{array}$ & Conventional & $\begin{array}{c}\text { Clinical outcomes } \\
\text { and mean NHS costs } \\
\text { per patient }\end{array}$ \\
\hline $\begin{array}{l}\text { Whited et al. } \\
\text { (19) }\end{array}$ & 2005 & USA & Diabetic populations & $\begin{array}{l}\text { Non-mydriatic digital tele- } \\
\text { ophthalmology system } \\
\text { (Joslin Vision Network) }\end{array}$ & $\begin{array}{l}\text { Traditional clinic- } \\
\text { based ophthalmoscopy } \\
\text { examinations with } \\
\text { pupil dilation }\end{array}$ & $\begin{array}{l}\text { The number of true } \\
\text { positive cases of } \\
\text { proliferative diabetic } \\
\text { retinopathy detected, } \\
\text { the number of } \\
\text { patients treated with } \\
\text { panretinal laser } \\
\text { photocoagulation, and } \\
\text { the number of cases } \\
\text { of severe vision loss } \\
\text { averted }\end{array}$ \\
\hline $\begin{array}{l}\text { Aoki et al. } \\
(20)\end{array}$ & 2004 & USA & $\begin{array}{c}\text { Prison inmates with type } \\
2 \text { diabetes }\end{array}$ & $\begin{array}{l}\text { Teleophthalmology in } \\
\text { evaluating diabetic } \\
\text { retinopathy }\end{array}$ & Nonteleophthalmology & $\begin{array}{l}\text { Cost per quality- } \\
\text { adjusted life } \\
\text { years(QALYs) }\end{array}$ \\
\hline $\begin{array}{l}\text { Loane et al. } \\
(21)\end{array}$ & 2001 & Australia & $\begin{array}{l}274 \text { patients required a } \\
\text { hospital outpatient der- } \\
\text { matology referral }\end{array}$ & Real time teledermatology & Conventional care & Cost per patient \\
\hline
\end{tabular}

indicated that the average annual cost of treatment was $\$$ 112 (range \$ 61 to \$259). During the 2-year follow-up, in the intervention group, inpatient costs were $\$ 7800$ and $\$ 9741$ for outpatient costs. In the non-intervention group, the costs of inpatient and outpatient costs were $\$ 6866$ and $\$ 9599$, respectively. Cost-effectiveness of behavioral interventions was in the range between about $\$ 42,457$ per gained life-year for women with normal weight and $\$ 87$, 300 per year life-year saved for men with the normalweight. Nurse-administered telemedicine via telephone can be cost effective for control of hypertension among veterans (9). Nelson et al. showed that compared with usual care, the incremental cost-effectiveness ratio of telestroke --a 2-way, audiovisual technology that links stroke specialists to remote emergency department physicians and their stroke patients-- was $\$ 108,363$ per QALY in 90 days and $\$ 2449$ per QALY in lifetime. With respect to lifetime, telestroke was cost-effective than usual care (11). Dowie et al. compared the clinical outcomes and costs of a telecardiology service with conventional faceto-face delivery for three time periods neonatal cot days, pediatric ward bed days, out-patient attendances, echocar- 
Telemedicine: A systematic review of economic evaluations

\begin{tabular}{|c|c|c|c|c|c|c|}
\hline $\begin{array}{l}\text { Author } \\
\text { (Reference) }\end{array}$ & Year & Country & Population & $\begin{array}{c}\text { Intervention } \\
\text { (Type of Telemedicine) }\end{array}$ & Comparison & Outcome Indicators \\
\hline $\begin{array}{l}\text { Wooton et al. } \\
\text { (22) }\end{array}$ & 2000 & Australia & $\begin{array}{c}204 \text { general } \\
\text { practice patients } \\
\text { requiring referral } \\
\text { to dermatology } \\
\text { services }\end{array}$ & Real time teledermatology & $\begin{array}{l}\text { Conventional } \\
\text { consultation }\end{array}$ & Cost-benefit analysis \\
\hline $\begin{array}{l}\text { Wu et al. } \\
(23)\end{array}$ & 1995 & USA & $\begin{array}{l}\text { Patients with } \\
\text { arrhythmias asso- } \\
\text { ciated with } \\
\text { intermittent cen- } \\
\text { tral nervous sys- } \\
\text { tem or cardiac } \\
\text { symptoms. }\end{array}$ & $\begin{array}{l}\text { Transtelephonic arrhythmia moni- } \\
\text { toring }\end{array}$ & Ambulatory ECG & Cost-effectiveness \\
\hline $\begin{array}{l}\text { Stoloff et al. } \\
(24)\end{array}$ & 1998 & USA & Patients & $\begin{array}{l}\text { Various technologies (telephone } \\
\text { and fax, e-mail and Internet, video } \\
\text { teleconferencing (VTC), teleradiol- } \\
\text { ogy, and diagnostic instruments }\end{array}$ & - & $\begin{array}{l}\text { The man-day savings and } \\
\text { quality-of-care enhance- } \\
\text { ments }\end{array}$ \\
\hline $\begin{array}{l}\text { Sicotte et al. } \\
(25)\end{array}$ & 2004 & Canada & $\begin{array}{l}\text { Children suffering } \\
\text { from cardiac } \\
\text { pathologies }\end{array}$ & $\begin{array}{c}\text { Paediatric cardiology teleconsulta- } \\
\text { tion }\end{array}$ & Conventional care & $\begin{array}{l}\text { Incremental cost- } \\
\text { effectiveness ratio, cost per } \\
\text { patient journey avoided }\end{array}$ \\
\hline $\begin{array}{l}\text { Kildemoes et al. } \\
(26)\end{array}$ & 2004 & Denmark & $\begin{array}{l}\text { Patients with } \\
\text { acute myocardial } \\
\text { infarction (AMI) }\end{array}$ & $\begin{array}{l}\text { The public campaign with } \\
\text { prehospital telemedicine } \\
\text { diagnostics }\end{array}$ & - & Cost per life year \\
\hline $\begin{array}{l}\text { Van der et al. } \\
(27)\end{array}$ & 2010 & Scotland & $\begin{array}{l}\text { Patients whose } \\
\text { symptoms sug- } \\
\text { gested possible } \\
\text { cancer of the } \\
\text { airways }\end{array}$ & Tele-endoscopy clinics & $\begin{array}{l}\text { Conventional, } \\
\text { mainland clinic }\end{array}$ & Average cost per patient \\
\hline $\begin{array}{l}\text { Jackson et al. } \\
(28)\end{array}$ & 2008 & USA & $\begin{array}{l}\text { Infants with BW } \\
\text { less than } 1251 \mathrm{~g}\end{array}$ & $\begin{array}{l}\text { Telemedicine for retinopathy of } \\
\text { prematurity (ROP) management }\end{array}$ & $\begin{array}{l}\text { Standard ophthal- } \\
\text { moscopy }\end{array}$ & $\begin{array}{l}\text { Costs per quality-adjusted } \\
\text { life year gained }\end{array}$ \\
\hline $\begin{array}{l}\text { Simon et al. } \\
(29)\end{array}$ & 2009 & USA & $\begin{array}{l}\text { Consecutive } \\
\text { primary care } \\
\text { patients starting } \\
\text { antidepressant } \\
\text { treatment }\end{array}$ & $\begin{array}{l}\text { Telephone care management and } \\
\text { telephone psychotherapy for de- } \\
\text { pression }\end{array}$ & Usual care & $\begin{array}{l}\text { Outpatient health care costs, } \\
\text { depression-free days, incre- } \\
\text { mental net benefit }\end{array}$ \\
\hline
\end{tabular}

diograms, medical staff time, ambulance transfers to London, and the telemedicine service including equipment, maintenance, rental of telephone, and network lines versus conventional face-to-face delivery were measured.

The mean six-monthly costs were $£ 6,337$ for telemedicine compared with $£ 4,294$ for conventional face-to-face consultation and it is not costly. Thus, telecardiology networks at least is cost-neutral in a situation that other telemedicine uses (18). Wu et al. demonstrated that in two groups consist of 48 consecutive patients and 43 ambulatory ECGS, at the department of veterans affairs medical center, Miami, USA, the cost per useful study for TTM (transtelephonic arrhythmia monitoring) was \$1577, Ambulatory ECGS was $\$ 3410$ and for the matched group of 43 ambulatory ECGS, was \$7883. TTM appeared more effective than ambulatory ECG for the detection of arrhythmias associated with the intermittent central nervous system or cardiac symptoms. Limiting TTM to patients with primarily cardiac symptoms, and to a 1 week time period, would have optimized cost-effectiveness in this group of patients (23). Sicotte et al. analyzed that the cost-effectiveness of a teleconsultation service after five years of operation on 78 children suffering from cardiac pathologies in tertiary care and a clinic from 1998 to 2001. The effectiveness analysis showed that the teleconsultation service was effective in reducing the number of visits. Total costs over this study were $\$ 272,327$ for teleconsultation and $\$ 157,212$ for conventional consultation and the sensitivity analysis showed that the teleconsultation strategy was the most costly. Teleconsultation was a good method for the diagnosis for children with cardiac pathologies but, the use of teleconsultation has extra costs in comparison with conventional consultation, because of the initial acquisition cost of the equipment (25). Kildemoes et al. in the review study which was about the costeffectiveness of interventions to reduce the thrombolytic delay for acute myocardial infarction found that the estimated net 5-year cost of the public campaign would be DKK 51.3 million, the estimated cost of pre-hospital telemedicine diagnostics was DKK 304.8 million. They concluded these programs are likely to have little impact on AMI (acute myocardial infarction) fatality (26).

\section{B) Pulmonary}

Agha et al. in their study revealed that telemedicine for the delivery of outpatient pulmonary care to a rural population can be more cost-effective ( $\$ 335$ per patient/year) compared with usual care (about $\$ 585$ per patient/year) and on-site care (\$1166 per patient/year). Sensitivity analysis showed that the cost-effectiveness of Telemedicine was sensitive to changes in the patient numbers, the probability of success through consulting Telemedicine, Telemedicine equipment costs and percentage of optimal effort provided by the local pulmonary specialist. Telemedicine can be a cost-effective strategy for delivering outpatient pulmonary care to rural populations which have 


\begin{tabular}{|c|c|c|}
\hline No. & Paper Title & Exclusion reasons \\
\hline 1 & $\begin{array}{l}\text { Cost-benefit of the telecardiology service in the state of Minas Gerais: Minas } \\
\text { Telecardio project }(30)\end{array}$ & Lack of relevant outcomes \\
\hline 2 & $\begin{array}{l}\text { Reducing the cost of frequent hospital admissions for congestive heart failure: a } \\
\text { randomized trial of a home telecare intervention (31) }\end{array}$ & Lack of relevancy between costs and outcomes \\
\hline 3 & $\begin{array}{l}\text { Clinical and economic outcomes of the electronic intensive care unit: results from } \\
\text { two community hospitals ( } 32 \text { ) }\end{array}$ & Lack of relevancy between costs and outcomes \\
\hline 4 & $\begin{array}{l}\text { Economic evaluation of telephone self-management interventions for blood } \\
\text { pressure control (33) }\end{array}$ & Lack of relevancy between costs and outcomes \\
\hline 5 & $\begin{array}{l}\text { Assessment of the clinical outcomes and cost-effectiveness of the management of } \\
\text { systolic heart failure in Chinese patients using a home-based intervention (34) }\end{array}$ & Lack of relevancy between costs and outcomes \\
\hline 6 & $\begin{array}{l}\text { Multicenter randomized trial on home-based telemanagement to prevent hospital } \\
\text { readmission of patients with chronic heart failure (35) }\end{array}$ & Lack of relevancy between costs and outcomes \\
\hline 7 & $\begin{array}{l}\text { The efficacy and cost-effectiveness of a community weight management } \\
\text { intervention: a randomized controlled trial of the health weight management } \\
\text { demonstration ( } 36)\end{array}$ & Lack of relevant control \\
\hline 8 & $\begin{array}{l}\text { Diagnostic and cost effectiveness of telemonitoring the pediatric pacemaker patient } \\
\text { (37) }\end{array}$ & Lack of relevancy between costs and outcomes \\
\hline 9 & $\begin{array}{l}\text { Are there time and cost savings by using telemanagement for patients on } \\
\text { intensified insulin therapy: a randomized, controlled trial (38) }\end{array}$ & Lack of relevancy between costs and outcomes \\
\hline 10 & $\begin{array}{l}\text { National use of thrombolysis with alteplase for acute ischaemic stroke via } \\
\text { telemedicine in Denmark: a model of budgetary impact and cost-effectiveness (39) }\end{array}$ & Lack of relevant control \\
\hline 11 & The cost-effectiveness of technology transfer using telemedicine (40) & Lack of relevant control and cost calculations \\
\hline 12 & $\begin{array}{l}\text { Economic analysis of a telemedicine intervention to improve glycemic control in } \\
\text { patients with diabetes mellitus: illustration of a novel analytic method (41) }\end{array}$ & Lack of relevant control \\
\hline 13 & $\begin{array}{l}\text { Effect of a multiple-site intensive care unit telemedicine program on clinical and } \\
\text { economic outcomes: an alternative paradigm for intensivist staffing (42) }\end{array}$ & Lack of cost calculations \\
\hline 14 & $\begin{array}{l}\text { Cost-effective use of telemedicine and self-monitoring of blood glucose via } \\
\text { Diabetes Tele Management System (DTMS) to achieve target glycosylated } \\
\text { hemoglobin values without serious symptomatic hypoglycemia in } 1,000 \text { subjects } \\
\text { with type } 2 \text { diabetes mellitus: a retrospective study (43) }\end{array}$ & Lack of relevant control and cost calculations \\
\hline 15 & $\begin{array}{l}\text { Cost-effectiveness analysis of a rural telemedicine collaborative care intervention } \\
\text { for depression (44) }\end{array}$ & Lack of relevant control \\
\hline 16 & $\begin{array}{l}\text { Costs and benefits of personalized healthcare for patients with chronic heart failure } \\
\text { in the care and education program "Telemedicine for the Heart" (45) }\end{array}$ & Lack of relevant control \\
\hline 17 & $\begin{array}{l}\text { Resource costs and quality of life outcomes for homebound elderly using } \\
\text { telemedicine integrated with nurse case management (46) }\end{array}$ & Lack of separate cost calculations \\
\hline 18 & Cost analysis of telehomecare (47) & Lack of relevant control and outcomes \\
\hline 19 & Home telehealth reduces healthcare costs $(48)$ & Lack of relevant control and cost calculations \\
\hline 20 & $\begin{array}{l}\text { Cost-effectiveness analysis of telemedical devices for pre-clinical traffic accident } \\
\text { emergency rescue in Germany (49) }\end{array}$ & Lack of relevant control \\
\hline
\end{tabular}

limited access to specialized services (10). Ryan et al. determined clinical, and cost effectiveness of mobile phone supported self-monitoring of asthma with a multicentre randomized controlled trial on 288 adolescents and adults with poorly controlled asthma. There was no significant difference between mobile technology asthma control and paper monitoring based on clinical guidelines .The mobile phone service was not cost effective because of the expenses of telemonitoring (14). Van der et al. accomplished that in comparison of Teleendoscopy in a remote location with conventional endoscopy at units on the mainland in Aberdeen in patients with symptoms suggesting the presence cancer of the airways. They found that the net benefits were larger for teleendoscopy than for the conventional clinics, and additional waiting time for tele-endoscopy was no longer than 3.8 weeks, so tele-endoscopy was the preferred option (27).

\section{C) Ophthalmology}

Rein et al. studied the cost-effectiveness of three screening alternatives for patients aged 30 or older with type 2 diabetes with no or early diabetic retinopathy. Telemedicine increased costs by $\$ 3,343$, biennial evaluation by $\$ 3,636$, and annual evaluation by $\$ 4,809$; and varying the discount rate from $0 \%$ to $5 \%$ only impacted the choice between biennial and annual evaluations and that annual evaluation was only more likely to be cost-effective at discount rates lower than our baseline. They found that telemedicine is not cost-effective for low-risk patients for annual eye evaluation but it is a costly diagnostic eye-care evaluation (15). Whited et al. examined a non-mydriatic digital teleophthalmology system, and conventional clinicbased ophthalmoscopy examination with pupil dilation for detecting proliferative diabetic retinopathy by three federal healthcare agencies for detecting proliferative diabetic retinopathy. They found that in all three federal healthcare agencies cost-savings of JVN (the Joslin Vision Network) were more than ophthalmoscopy, pan-retinal laser photocoagulation and accounting for severe vision loss cases (19). Aoki et al. compared two screening strategies for analysis of teleophthalmology and non-teleophthalmology cost-effectiveness in order to detect diabetic retinopathy in prison inmates with Type 2 diabetes. They resulted that health benefits were discounted at an annual rate of $3 \%$. The teleophthalmology strategy resulted in an average of 18.73 QALYs and the non-teleophthalmology strategy in an average of 18.58 QALYs. In the teleophthalmology strategy, $12.4 \%$ of patients reached blindness versus 
$20.5 \%$ in the non-teleophthalmology strategy. The absolute risk reduction for blindness was $8.1 \%$. The numberneeded-to-screen was 12.4 . The total cost per patient was $\$ 16,514$ in the teleophthalmology group and $\$ 17,590$ in the non-teleophthalmology group. So teleophthalmology is more cost-effective than face-to-face examination for evaluating diabetic retinopathy (20). Jackson et al. studied cost-utility analysis of telemedicine and standard ophthalmoscopy for retinopathy of prematurity management. For infants with birth weight less than $1500 \mathrm{~g}$ the costs per quality-adjusted life year gained $\$ 3193$ with telemedicine and $\$ 5617$ with standard ophthalmoscopy. They concluded telemedicine is more cost-effective than standard ophthalmoscopy for retinopathy of prematurity (ROP) management and both of them are highly cost-effective compared with other health care interventions (28).

\section{D) Dermatology}

Eminović et al. analyzed the cost minimization of teledermatology, and conventional process costs based on clustered randomized trial to investigate what extent and under which conditions store-and-forward teledermatology can reduce costs from a societal perspective. Findings showed total mean costs of teledermatology process $(€ 387)$ were higher than the total mean costs of conventional process costs $(€ 354)$; it means teledermatology process costs in $89 \%$ of all simulations were more expensive and it should be applied in only those cases with a reasonable probability that a live consultation can be prevented (17). Loane et al. performed a randomized controlled trial on the health economics of teledermatology care with conventional outpatient care in urban and rural perspective. From the patient perspective, telemedicine was cheaper than conventional care as it involved less travel and time costs. From the hospital perspective, telemedicine was only marginally more expensive than conventional care when current equipment prices were used in the calculations. Indeed, from the hospital viewpoint, the marginal cost of the telemedicine consultation was lower than that of the conventional consultation when current prices were used. Using a real-world scenario in urban areas the average cost of telemedicine and conventional consultation were about equal, while in rural areas the average cost of telemedicine consultation was less than that of conventional consultation (21). Wooton et al. demonstrated that in four heath center (two urban, two rural) and two regional hospitals with 204 dermatology patients, 102 teledermatology patients and 102 to traditional outpatient consultation, the net societal cost of initial consultation was $\$ 132.10$ per patient for teledermatology and $\$ 48.73$ for conventional consultation. Sensitivity analysis revealed that if each health center had allocated one morning session a week to teledermatology and the average round trip to the hospital had been $78 \mathrm{~km}$ instead of $26 \mathrm{~km}$, the costs of the two methods of care would have been equal. Real time teledermatology was clinically feasible but not cost-effective compared with conventional dermatological outpatient care (22).

\section{Other indications of use}

Graves et al. indicated that telephone counseling intervention for physical activity and diet compared with usual care was not cost-effective (\$ 78,489 per QALY gained). Usual care (brief intervention) compared with real practice (Real Control) was cost-effective (\$ 12,153 per QALY gained). The decision to adopt telephone counseling program in real practice (Real Control) seems to be costeffective (12). Crow et al. found that cognitive behavior therapy for Bulimia Nervosa provided by telemedicine may be cost-effective than face to face therapy in a broad geographic area. This alternative approach offers hope for treatment with high expertise in the field of eating disorders and may be used in other types of psychopathology (13). Franzini et al. estimated the costs and costeffectiveness of a telemedicine intensive care unit (ICU) (tele-ICU) program with an observational study on an independent group of patients. ICU care complications, the length of stay, and short-term mortality are all measured. The cost of the tele-ICU program consisted of hourly, monthly per bed fees and telemedicine ICU capital costs were annualized. After the implementation of the tele-ICU, the increase of hospital daily cost (24\%); hospital cost per case, $(43 \%)$; and the cost per patient $(28 \%)$ were seen. They showed tele-ICU, was cost-effective in the sickest patients because it decreased hospital mortality without increasing costs significantly (16). Stoloff et al. found that if telemedicine were available to the fleet, ship medical staffs would initiate nearly 19, 000 consults in a year- $7 \%$ of all patient visits. Telemedicine would enhance the quality of care in two-thirds of these consults. Seventeen percent of the (medical evacuations) MEDEVACs would be preventable with telemedicine, with a savings of $\$ 4400$ per MEDEVAC. If the ship's communication capabilities were available, e-mail and internet and telephone and fax would be cost-effective on all ships (24). Simon et al. studied on incremental benefit and cost of telephone care management and telephone psychotherapy for depression in seven primary care clinics of a prepaid health care plan in Washington. They found structured telephone program including care management and cognitive behavioral psychotherapy with a modest increase in health services cost has more clinical benefit than current primary care practice (29).

\section{Discussion}

The present study is one of the few studies that systematically review the economic evaluation studies in the field of telemedicine. According to the included studies and telemedicine indications of use which were applied in this paper as major themes for synthesizing of retrieved data, it seems that using telemedicine in cardiology can be effective and cost-effective enough $(9,11,18,23,25)$ but in this field, one of the included papers expressed that prehospital telemedicine diagnostics program are likely to have little impact on acute myocardial infarction fatality (26). In pulmonary indications of use, one paper showed that telemedicine can be a cost-effective strategy for delivering outpatient pulmonary care to rural populations which have limited access to specialized services (10), but 
two papers expressed that telemedicine isn't cost effective in asthma and airways cancer $(14,27)$. In ophthalmology, four studies found that in diabetic retinopathy, the use of telemedicine is a cost-effective tool for diagnosis of this disease $(15,19,20,28)$. In dermatology, three papers expressed that telemedicine in dermatology isn't cost effective enough in comparison of conventional cares $(17,21$, 22). In other fields such as physical activity and diet, eating disorder, tele-ICU, psychotherapy for depression and telemedicine on ships, included studies found that telemedicine can be used as a cost-effective tool for cares and treatments $(12,13,16,24,29)$. Our findings showed that all included studies were conducted in high-income countries. 12 studies in USA, 3 in Australia, 2 in the UK, and one study in Canada, Denmark, and Scotland and Netherlands was conducted. Our findings surprisingly showed that telemedicine in low-income countries with limited resources is underused. Telemedicine in low-income countries with lack of resources, inadequate infrastructure and a shortage of doctors and other health care workforce, can be used as an innovative solution that reduces many costs, including travel costs and increase access to health care; given that telemedicine requires the application of modern technology, it is used less in such settings. Considering cheaper and non-real-time (store-and-forward) telemedicine that has the largest applicability in these settings, we recommended pilot projects on costeffectiveness of telemedicine programs in low-income countries.

This study has some limitations. Our evidence for the cost-effectiveness of telemedicine was inconsistent, across a wide range of fields. It suggested future studies focus on special telemedicine intervention. Also because of existing country-specific variations in the health systems, it is problematic to generalize the cost-effectiveness of telemedicine interventions from one country to another. Generalizability of cost-effectiveness of telemedicine interventions depends on the exclusive contextual aspects of the telemedicine service being implemented. Hence, it is suggested, especially in regions with low resources to conduct local cost-effectiveness analysis of the telemedicine systems.

\section{Conclusion}

In conclusion, the most of the included studies confirmed that telemedicine is cost effective for applying in major medical fields such as cardiology and so on, but just in dermatology, papers could not confirm the positive capability of telemedicine.

\section{Conflict of Interests}

The authors declare that they have no competing interests.

\section{References}

1. Mazurek C, Stroinski M. Innovative ICT Platform for Emerging eHealth Services: Towards Overcoming Technical and Social Barriers and Solving Grand Challenges in Medicine. In2010 Second International Conference on eHealth, Telemedicine, and Social Medicine 2010 Feb 10 (pp. 33-38). IEEE.
2. Whited JD, Hall RP, Foy ME, Marbrey LE, Grambow SC, Dudley TK, et al. Teledermatology's impact on time to intervention among referrals to a dermatology consult service. Telemed J E-Health. 2002;8(3):313-21.

3. Berman M, Fenaughty A. Technology and managed care: patient benefits of telemedicine in a rural health care network. Health Econ. 2005; 14(6):559-73.

4. Mair F, Whitten P. Systematic review of studies of patient satisfaction with telemedicine. BMJ. 2000;320(7248):1517-20.

5. Dávalos ME, French MT, Burdick AE, Simmons SC. Economic evaluation of telemedicine: review of the literature and research guidelines for benefit-cost analysis. Telemed E-Health. 2009; 15(10):933-48.

6 . Whited JD. Economic analysis of telemedicine and the teledermatology paradigm. Telemed E-Health. 2010;16(2):223-8.

7. Jennett PA, Hall LA, Hailey D, Ohinmaa A, Anderson C, Thomas R, et al. The socio-economic impact of telehealth: a systematic review. J Telemed Telecare. 2003;9(6):311-20.

8. Ekeland AG, Bowes A, Flottorp S. Effectiveness of telemedicine: a systematic review of reviews. Int J Med Inform. 2010;79(11):736-71.

9. Datta SK, Oddone EZ, Olsen MK, Orr M, McCant F, Gentry P, et al. Economic analysis of a tailored behavioral intervention to improve blood pressure control for primary care patients. Am Heart J. 2010;160(2):257-63.

10. Agha Z, Schapira RM, Maker AH. Cost effectiveness of telemedicine for the delivery of outpatient pulmonary care to a rural population. Telemed J E-Health. 2002;8(3):281-91.

11. Nelson RE, Saltzman GM, Skalabrin EJ, Demaerschalk BM, Majersik JJ. The cost-effectiveness of telestroke in the treatment of acute ischemic stroke. Neurology. 2011;77(17):1590-8.

12. Graves N, Barnett AG, Halton KA, Veerman JL, Winkler E, Owen $\mathrm{N}$, et al. Cost-effectiveness of a telephone-delivered intervention for physical activity and diet. PloS one. 2009;4(9):e7135.

13. Crow SJ, Mitchell JE, Crosby RD, Swanson SA, Wonderlich S, Lancanster K. The cost effectiveness of cognitive behavioral therapy for bulimia nervosa delivered via telemedicine versus face-to-face. Behav Res Ther. 2009; 47(6):451-3.

14. Ryan D, Price D, Musgrave SD, Malhotra S, Lee AJ, Ayansina D, et al. Clinical and cost effectiveness of mobile phone supported self monitoring of asthma: multicentre randomised controlled trial. BMJ. 2012; 344:e1756.

15. Rein DB, Wittenborn JS, Zhang X, Allaire BA, Song MS, Klein R, et al. The Cost-Effectiveness of Three Screening Alternatives for People with Diabetes with No or Early Diabetic Retinopathy. Health Serv Res. 2011;46(5):1534-61.

16. Franzini L, Sail KR, Thomas EJ, Wueste L. Costs and costeffectiveness of a telemedicine intensive care unit program in 6 intensive care units in a large health care system. J Crit Care. 2011; 26(3):329-e1.

17. Eminović N, Dijkgraaf MG, Berghout RM, Prins AH, Bindels PJ, de Keizer NF. A cost minimisation analysis in teledermatology: modelbased approach. BMC Health Serv Res. 2010; 10(1):1.

18. Dowie R, Mistry H, Rigby M, Young TA, Weatherburn G, Rowlinson G, et al. A paediatric telecardiology service for district hospitals in south-east England: an observational study. Arch Dis Child.2009;94(4):273-7.

19. Whited JD, Datta SK, Aiello LM, Aiello LP, Cavallerano JD, Conlin PR, et al. A modeled economic analysis of a digital teleophthalmology system as used by three federal healthcare agencies for detecting proliferative diabetic retinopathy. Telemed J E-Health. 2005;11(6):64151 .

20. Aoki N, Dunn K, Fukui T, Beck JR, Schull WJ, Li HK. Costeffectiveness analysis of telemedicine to evaluate diabetic retinopathy in a prison population. Diabetes care. 2004;27(5):1095-101.

21. Loane MA, Bloomer SE, Corbett R, Eedy DJ, Evans C, Hicks N, et al. A randomized controlled trial assessing the health economics of realtime teledermatology compared with conventional care: an urban versus rural perspective. J Telemed Telecare. 2001;7(2):108-18.

22. Wootton R, Bloomer SE, Corbett R, Eedy DJ, Hicks N, Lotery HE, et al. Multicentre randomised control trial comparing real time teledermatology with conventional outpatient dermatological care: societal cost-benefit analysis. BMJ. 2000;320(7244):1252-6.

23. Wu J, Kessler DK, Chakko S, Kessler KM. A cost-effectiveness strategy for transtelephonic arrhythmia monitoring. Am J Cardiol. 1995;75(2):184-5.

24. Stoloff P, Garcia F, Thomason J, Shia D. A cost-effectiveness analy- 
sis of shipboard telemedicine. Telemed J. 1998;4(4):293-304.

25. Sicotte C, Lehoux P, Van Doesburg N, Cardinal G, Leblanc Y. A cost-effectiveness analysis of interactive paediatric telecardiology. J Telemed Telecare. 2004;10(2):78-83.

26. Kildemoes HW, Kristiansen IS. Cost-effectiveness of interventions to reduce the thrombolytic delay for acute myocardial infarction. Int $\mathbf{J}$ Technol Assess. 2004;20(03):368-74.

27. Van Der Pol M, Mckenzie L. Costs and benefits of tele-endoscopy clinics in a remote location. J Telemed Telecare. 2010;16(2):89-94.

28. Jackson KM, Scott KE, Zivin JG, Bateman DA, Flynn JT, Keenan JD, et al. Cost-utility analysis of telemedicine and ophthalmoscopy for retinopathy of prematurity management. Arch Ophthalmol-Chic. 2008;126(4):493-9.

29. Simon GE, Ludman EJ, Rutter CM. Incremental benefit and cost of telephone care management and telephone psychotherapy for depression in primary care. Arch Gen Psychiat. 2009;66(10):1081-9.

30. Andrade MV, Maia AC, Cardoso CS, Alkmim MB, Ribeiro AL. Cost-benefit of the telecardiology service in the state of Minas Gerais: Minas Telecardio Project. Arq Bras Psicol Apl. 2011;97(4):307-16.

31. Jerant AF, Azari R, Nesbitt TS. Reducing the cost of frequent hospital admissions for congestive heart failure: a randomized trial of a home telecare intervention. Med Care. 2001;39(11):1234-45.

32. Morrison JL, Cai Q, Davis N, Yan Y, Berbaum ML, Ries M, et al. Clinical and economic outcomes of the electronic intensive care unit: Results from two community hospitals. Crit Care Med. 2010;38(1):28 .

33. Wang V, Smith VA, Bosworth HB, Oddone EZ, Olsen MK, McCant $\mathrm{F}$, et al. Economic evaluation of telephone self-management interventions for blood pressure control. Am Heart J. 2012; 163(6):980-6.

34. Chen YH, Ho YL, Huang HC, Wu HW, Lee CY, Hsu TP, et al. Assessment of the clinical outcomes and cost-effectiveness of the management of systolic heart failure in Chinese patients using a homebased intervention. J Int Med Res. 2010; 38(1):242-52.

35. Giordano A, Scalvini S, Zanelli E, Corrà U, Longobardi GL, Ricci $\mathrm{VA}$, et al. Multicenter randomised trial on home-based telemanagement to prevent hospital readmission of patients with chronic heart failure. Int J Cardiol. 2009;131(2):192-9.

36. Hersey JC, Khavjou O, Strange LB, Atkinson RL, Blair SN, Campbell $\mathrm{S}$, et al. The efficacy and cost-effectiveness of a community weight management intervention: a randomized controlled trial of the health weight management demonstration. Prev Med. 2012; 54(1):429 .

37. Vincent JA, Cavitt DL, Karpawich PP. Diagnostic and cost effectiveness of telemonitoring the pediatric pacemaker patient. Pediatr Cardiol. 1997; 18(2):86-90.

38. Biermann E, Dietrich W, Rihl J, Standl E. Are there time and cost savings by using telemanagement for patients on intensified insulin therapy?: A randomised, controlled trial. Comput Meth Prog Bio. 2002;69(2):137-46

39. Ehlers L, Müskens WM, Jensen LG, Kjølby M, Andersen G. National Use of Thrombolysis with Alteplase for Acute Ischaemic Stroke via Telemedicine in Denmark. CNS drugs. 2008; 22(1):73-81.

40. Johnston K, Kennedy C, Murdoch I, Taylor P, Cook C. The costeffectiveness of technology transfer using telemedicine. Health Policy Plann. 2004; 19(5):302-9.

41. Mason JM, Young RJ, New JP, Gibson JM, Long AF, Gambling T, et al. Economic analysis of a telemedicine intervention to improve glycemic control in patients with diabetes mellitus. Dis Manag Health Out. 2006; 14(6):377-85.

42. Breslow MJ, Rosenfeld BA, Doerfler M, Burke G, Yates G, Stone DJ, et al. Effect of a multiple-site intensive care unit telemedicine program on clinical and economic outcomes: an alternative paradigm for intensivist staffing. Crit Care Med. 2004; 32(1):31-8

43. Kesavadev J, Shankar A, Pillai PB, Krishnan G, Jothydev S. Costeffective use of telemedicine and self-monitoring of blood glucose via Diabetes Tele Management System (DTMS) to achieve target glycosylated hemoglobin values without serious symptomatic hypoglycemia in 1,000 subjects with type 2 diabetes mellitus-A retrospective study. Diabetes Technol The. 2012; 14(9):772-6.

44. Pyne JM, Fortney JC, Tripathi SP, Maciejewski ML, Edlund MJ, Williams DK. Cost-effectiveness analysis of a rural telemedicine collaborative care intervention for depression. Arch Gen Psychiat. 2010 Aug 1; 67(8):812-21.

45. Sohn S, Helms TM, Pelleter JT, Müller A, Kröttinger AI, Schöffski

O. Costs and benefits of personalized healthcare for patients with chronic heart failure in the care and education program "Telemedicine for the Heart". Telemed E-Health. 2012; 18(3):198-204.

46. Noel HC, Vogel DC. Resource costs and quality of life outcomes for homebound elderly using telemedicine integrated with nurse case management. Care management-Fair field CT. 2000;6(5):22-31.

47. Dansky KH, Palmer L, Shea D, Bowles KH. Cost analysis of telehomecare. Telemed J E-Health. 2001; 7(3):225-32.

48. Noel HC, Vogel DC, Erdos JJ, Cornwall D, Levin F. Home telehealth reduces healthcare costs. Telemed J E-Health. 2004 Jun 1; $10(2): 170-83$

49. Auerbach H, Schreyögg J, Busse R. Cost-effectiveness analysis of telemedical devices for pre-clinical traffic accident emergency rescue in Germany. Technol Health Care. 2006; 14(3):189-97. 